\title{
In vitro morphogenetic responses and comparative analysis of phthalides in the highly valued medicinal plant Ligusticum porteri Coulter \& Rose
}

\author{
Dalia Goldhaber-Pasillas $\cdot$ Robert Bye $\cdot$ \\ Víctor Manuel Chávez-Ávila · Rachel Mata
}

Received: 13 October 2011/ Accepted: 4 February 2012/Published online: 17 February 2012

(C) The Author(s) 2012. This article is published with open access at Springerlink.com

\begin{abstract}
The morphogenetic response of Ligusticum porteri, a medicinal and ceremonial plant, was investigated as part of the conservation strategy of this wild species and was compared to that of a cultivated species, Petroselinum crispum. Seeds were germinated in half strength Murashige and Skoog medium. Plantlets were excised into root, cotyledon, petiole, stem and leaf explants and cultured in an induction medium supplemented with the range of 0-18.09 $\mu \mathrm{M}$ 2,4-dichlorophenoxyacetic acid (2,4-D) or $0-21.48 \mu \mathrm{M} \alpha$-naphthaleneacetic acid in combination with 0-13.31 $\mu \mathrm{M}$ 6-benzylaminopurine. Calli derived from leaf, seeds, petiole, stem and roots, mature aerial parts and roots extracts of $L$. porteri and $P$. crispum were analyzed by thin layer chromatography and gas chromatography coupled to mass spectrometry. 3-Butylidenephthalide (6.3\%) was identified along with other 23 compounds from mature aerial parts extract of $L$. porteri and also in its roots (20.8\%). 3-nButylphthalide $(0.7 \%)$ and 3,6,7,-trimethoxy-isobenzofuran13(H)-one (4.9\%) were identified from the roots of P. crispum.
\end{abstract}

D. Goldhaber-Pasillas $(\square) \cdot$ R. Bye

Labotarorio de Etnobotánica, Jardín Botánico del Instituto de Biología, Universidad Nacional Autónoma de México,

Circuito Exterior s/n, Coyoacán, 04510 México D.F., Mexico

e-mail: daliagoldhaber@gmail.com

V. M. Chávez-Ávila

Laboratorio de Cultivo de Tejidos Vegetales, Jardín Botánico del Instituto de Biología, Universidad Nacional Autónoma de México, Circuito Exterior s/n, Coyoacán, 04510 México D.F., Mexico

R. Mata

Laboratorio 124, Departamento de Farmacia, Facultad de Química, Anexo E, Universidad Nacional Autónoma de México, Circuito Escolar, Copilco, 04510 México D.F., Mexico
3-Butylidenephthalide was identified from two petiole $(0.9 \%$; $0.26 \%)$ and one stem $(0.8 \%)$ callus extracts of $L$. porteri. This is the first report on phthalides production from in vitro cultures of $L$. porteri. The results indicated that in vitro cultures of this plant possess the biosynthetic machinery for the biosynthesis of these highly valuable compounds.

Keywords Ligusticum porteri - Petroselinum crispum . Apiaceae $\cdot$ Callus culture $\cdot$ Phthalides

$\begin{array}{ll}\text { Abbreviations } \\ \text { MS } & \text { Murashige and Skoog } \\ \text { 2,4-D } & \text { 2,4-Dichlorophenoxyacetic acid } \\ \text { NAA } & \alpha \text {-Naphthaleneacetic acid } \\ \text { BA } & \text { 6-Benzylaminopurine } \\ \text { GA }_{3} & \text { Gibberellic acid } \\ \text { TLC } & \text { Thin layer chromatography } \\ \text { GC-MS } & \text { Gas chromatography coupled to mass } \\ & \text { spectrometry } \\ \text { TTZ } & \text { 2,3,5-triphenyl-2H-tetrazolium chloride } \\ \text { PPM } & \text { Plant preservative mixture } \\ \text { PCV } & \text { Packed cell volume }\end{array}$

Introduction

Ligusticum porteri Coulter \& Rose (Apiaceae), "chuchupate", is a perennial herb that produces a thick vertical rootstock with crown of vascular bundles from decayed petioles at the top and a strong characteristic odor (Linares and Bye 1987). It grows in pine-oak forests of the southern and central Rocky Mountains of the United States and the northern Sierra Madre Occidental of Mexico (Cronquist 1997). 
In the Mexican folk medicine, L. porteri is highly prized for medicinal and ceremonial purposes by Tarahumara, Pimas, Zuni, Pauite and Mescalero Apache people (Linares and Bye 1987; Camazine and Bye 1980). Concoctions of the root are employed in the treatment of gastrointestinal disorders, such as stomachache, colic, ulcer and diarrhea, as well as headache, fever, cold, sore throat, wound, rheum, pain, bronchitis, pneumonia, tuberculosis and scorpion bites (Linares and Bye 1987). Portions of the root are used as a talisman to ward off witches and prevent snakebites as well as a good luck charm (Appelt 1985; Ortíz et al. 2007; Bye 1985).

Phthalides are reported to be the biologically active compounds responsible for the therapeutic action of this species. They have smooth muscle relaxant activity (Du et al. 2006), vasorelaxing activity (Chan et al. 2006), analgesic, neuroprotective (Peng et al. 2007; Kuang et al. 2006), antisclerotic, antihypertensive (Lu et al. 2006), serotonergic (Deng et al. 2006a), GABAergic (Deng et al. 2006b), antiproliferative (Liang and He 2006), antihyperglycemic (Brindis et al. 2011), sedative and spasmolytic (León et al. 2011). These compounds have been found in some genera of the Apiaceae including Angelica (Lao et al. 2004), Anethum (Fischer and Gijbels 1987), Apium (MacLeod et al. 1988), Bifora (Gijbels et al. 1985), Capnophyllum (Gijbels et al. 1984), Cnidium (Gijbels et al. 1981), Conioselinum (Gijbels et al. 1979), Levisticum (Santos et al. 2005), Ligusticum (Delgado et al. 1988), Lomatium (Bairamian et al. 2004), Opopanax (Gijbels et al. 1983), Petroselinum (Gijbels et al. 1985), Peucedanum (Gijbels et al. 1984) and Meum (Palá-Paúl et al. 2004).

Because of the overexploitation of its roots to satisfy the increasing demand of these molecules and the reduction of natural populations due to habitat destruction, a conservation strategy for L. porteri is highly required. Conventional cultivation has been hindered because of its asynchronous and low rate of seed germination. In vitro germination and micropropagation provide biotechnological alternatives for the production of plants for forest revegetation as well as in vitro synthesis of bioactive compounds. A first step in this process is to establish and evaluate the in vitro morphogenetic responses of $L$. porteri. We undertook this study because little is known about its natural reproduction and nothing has been reported about its morphogenetic and biosynthetic responses under in vitro conditions. Results were compared to those of Petroselinum crispum (Mill.) Nyman ex A.W. Hill, a cultivated species of the Apiaceae, that also biosynthesizes phthalides. Finally, the presence of phthalides in the root and callus extracts of $L$. porteri and $P$. crispum was assessed by thin layer chromatography (TLC) and gas chromatography coupled to mass spectrometry (GC-MS).

\section{Materials and methods}

Plant material

Mature seeds (technically modified fruits known as mericarps) and leaves of $L$. porteri were collected from wild plants in the pine-oak forests near Norogachi, Municipio of Guachochi, Chihuahua, Mexico, in October of 2005 (specimen voucher BYE 34467). After cleaning the seeds, they were stored at $1^{\circ} \mathrm{C}$ for 45 days. In the case of P. crispum, seeds of the commercial brand "Semillas Vita" (Rancho Los Molinos S. P. R. de R. L. Morelos, Mexico) were purchased from a local market. Seed viability was tested using the 2,3,5-triphenyl-2H-tetrazolium chloride (TTZ) conventional technique (Schmidt 2000).

\section{Ex vitro germination}

Cold pretreated and not-pretreated seeds of $L$. porteri were placed in pots $(30 \times 30 \mathrm{~cm})$ with different mixtures of substrates: (a) Sphagnum and soil (1:1 v/v), (b) agrolite, (c) soil and agrolite $(1: 1 \mathrm{v} / \mathrm{v})$ and (d) soil. These were kept in greenhouse conditions.

\section{In vitro germination}

In order to obtain axenic seedlings of $L$. porteri and $P$. crispum, the surface disinfected seeds were germinated in $100 \mathrm{~mL}$ jars containing $25 \mathrm{~mL}$ of a half strength Murashige and Skoog (1962) medium with $30 \mathrm{~g} \mathrm{~L}^{-1}$ sucrose, which was solidified with $4 \mathrm{~g} \mathrm{~L}^{-1}$ Gelrite (w/v) (PhytoTechnology Laboratories $^{\circledR}$, Shawnee Mission, KS, USA). The $\mathrm{pH}$ of the medium was adjusted to 5.7 prior autoclaving at $120^{\circ} \mathrm{C}$ and $103 \mathrm{kPa}$ for $17 \mathrm{~min}$. The pericarp was removed with tweezers after $1 \mathrm{~h}$ stirring the seeds in tap water. Surface disinfection was carried out by subjecting sequentially the seeds to the following process: tap water and commercial detergent for $20 \mathrm{~min}$, a solution of hydrogen peroxide $(7 \% \mathrm{v} / \mathrm{v})$ for $7 \mathrm{~min}$, a solution of terramycin $\left(2 \mathrm{~g} \mathrm{~L}^{-1}\right)$ for $10 \mathrm{~min}$, a solution of cuprimicin $\left(3 \mathrm{~g} \mathrm{~L}^{-1}\right)$ for $10 \mathrm{~min}$, a solution of sodium hypochlorite (domestic bleach $10 \% \mathrm{v} / \mathrm{v}$ ) for $10 \mathrm{~min}$ and, finally, a solution of Plant Preservative Mixture ${ }^{\mathrm{TM}}$ (PPM) (Plant Cell Technology, Washington, DC, USA) $\left(20.4 \mathrm{~mL} \mathrm{~L}^{-1}\right)$ for $2 \mathrm{~h}$. Seeds were incubated at $21^{\circ} \mathrm{C}$ in darkness and after germination transferred to fluorescent light $\left(13.5 \mu \mathrm{mol} \mathrm{m} \mathrm{m}^{-2} \mathrm{~s}^{-1}\right)$ with a $16 \mathrm{~h}$ light and $8 \mathrm{~h}$ dark photoperiod.

Callus induction media and cell cultures

10-20 weeks old plantlets of $L$. porteri and P. crispum were excised to produce cotyledon, hypocotyl, stem, root, leaf 
and petiole explants that were cultured in a half strength Murashige and Skoog (MS) medium and $30 \mathrm{~g} \mathrm{~L}^{-1}$ sucrose supplemented with 2,4-D (0, 0.45, 1.81, 4.52, 9.05, 13.57, and $18.09 \mu \mathrm{M})$ in combination with benzylaminopurine (BA) $(0,2.22,4.44,8.87$, and $13.31 \mu \mathrm{M})$ or $\alpha$-naphthaleneacetic (NAA) $(0,0.54,2.69,5.37,10.74,16.11$, and $21.48 \mu \mathrm{M})$ in combination with BA $(0,2.22,4.44,8.87$, $13.31 \mu \mathrm{M}$ ) and incubated at $21^{\circ} \mathrm{C}$ under a photoperiod for 30 days. To develop suspension culture, callus forming explants were transferred to a half strength liquid MS media with their respective plant growth regulator treatment.

Growth kinetics and determination of fresh weight

A series of 20 glass flasks of $100 \mathrm{~mL}$ volume, each containing $25 \mathrm{~mL}$ of culture medium, were inoculated individually with $5 \mathrm{~mL}$ of an established cell suspension culture and allowed to grow for 30-90 days in a rotary shaker $(90 \mathrm{rpm})$ at $21^{\circ} \mathrm{C}$. The growth was terminated on alternate days by taking 3 aliquots of $1 \mathrm{~mL}$ and placed in $1.5 \mathrm{~mL}$ sterile Eppendorf tubes. The suspension growth was measured by packed cell volume (PCV) (Street 1977). Each sample tube was centrifuged in an Eppendorf 5415D centrifuge at 2,600 rpm for $3 \mathrm{~min}$ and then the PCV was weighed in an analytic balance. Different stages of the growth curve were analyzed with a photomicroscope Axoskop C Zeiss both in clear and contrast phases. Samples were stored in the dark at $1^{\circ} \mathrm{C}$.

\section{Extraction of plants}

Material derived from roots (1.52 g), aerial parts (126 g) of $L$. porteri and roots of $P$. crispum $(4.30 \mathrm{~g})$ from greenhouse and field collections were powdered and macerated $(500 \mathrm{~mL})$ with a mixture of methylene chloride-methanol (analytical grade) 1:1 v/v at room temperature for 7 days in complete darkness. The resulting extracts were concentrated by distillation in a vacuum rotary evaporator at $60^{\circ} \mathrm{C}$ to yield a $0.17,11.37$ and $0.38 \mathrm{~g}$ crude extracts, respectively. All extracts were analyzed by TLC with Z-ligustilide (1) and diligustilide as standard references. All extracts were further analyzed by GC-MS. The aerial parts extract was subjected to silica gel column chromatography (250 g), eluting with a hexane-ethyl acetate (analytical grade) gradient (10:0 $\rightarrow$ $0: 10)$. The eluents were combined to yield eight fractions on the basis of TLC analysis. Fractions I, II, III-A, III-B, IV, V, VI and VII were further analyzed by GC-MS.

Extraction of calli

Material derived from in vitro callus cultures of root (32 mg), cotyledon (28 mg), seeds (7 mg), leaf (228.5 mg), root $(50.2 \mathrm{mg})$, petiole $(270.5 \mathrm{mg})$, stem $(49 \mathrm{mg})$, petiole
(136 mg), root (53 mg) and petiole (52 mg) were processed as mentioned above and analyzed by TLC and GC-MS. Treatment conditions are listed in Table 1.

TLC assay

A $1 \mu \mathrm{L}$ aliquot of extracts were spotted on silica-gel aluminum plates $(\mathrm{F} 254,10 \times 20 \mathrm{~cm} \times 0.25 \mathrm{~mm}$, Merck, Germany) and developed with the mobile phase with toluene:ethyl acetate:acetic acid 90:10:1 v/v/v. A $1 \mu \mathrm{g}$ of $Z$-ligustilide was spotted as positive standard.

GC-MS conditions

GC-MS analyses were carried out using an Agilent Technologies $6890 \mathrm{~N}$ chromatograph with a split injector (split relation 1/50) coupled to a LECO Pegasus 4D mass spectrometer. The MS detector was used in the electron impact ionization (EI) with an ionization voltage of $70 \mathrm{eV}$, using a total swept of spectra from 45 to $800 \mathrm{~m} / \mathrm{z}$. The

Table 1 Culture conditions of the analyzed calli of L. porteri

\begin{tabular}{ll}
\hline Explant & Plant growth regulator combination \\
\hline Cotyledon & 2,4-D $(13.57 \mu \mathrm{M}) / \mathrm{BA}(4.44 \mu \mathrm{M})$ \\
Leaf & 2,4-D $(18.09 \mu \mathrm{M}) / \mathrm{BA}(4.44 \mu \mathrm{M})$ \\
Petiole I & 2,4-D $(18.09 \mu \mathrm{M}) / \mathrm{BA}(2.22 \mu \mathrm{M})$ \\
Petiole II & 2,4-D $(0.45 \mu \mathrm{M}) / \mathrm{BA}(4.44 \mu \mathrm{M})$ \\
Petiole III & 2,4-D $(0.45 \mu \mathrm{M}) / \mathrm{BA}(13.31 \mu \mathrm{M})$ \\
Root I & 2,4-D $(13.57 \mu \mathrm{M}) / \mathrm{BA}(4.44 \mu \mathrm{M})$ \\
Root II & NAA $(5.37 \mu \mathrm{M}) / \mathrm{BA}(4.44 \mu \mathrm{M})$ \\
Root III & NAA $(21.48 \mu \mathrm{M}) / \mathrm{BA}(8.87 \mu \mathrm{M})$ \\
Seeds & GA $(28.89 \mu \mathrm{M})$ \\
Stem & 2,4-D $(0.45 \mu \mathrm{M}) / \mathrm{BA}(13.31 \mu \mathrm{M})$ \\
\hline
\end{tabular}

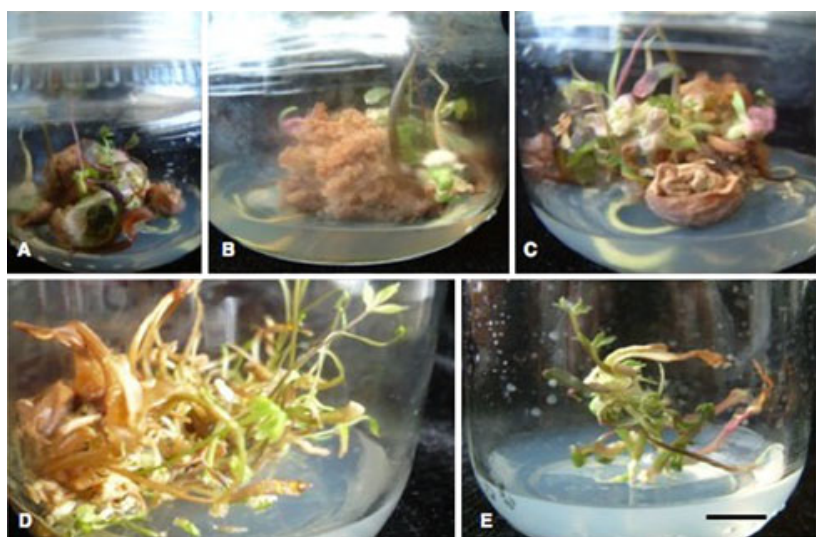

Fig. 1 Seeds of L. porteri germinated in vitro. a-c Seeds pretreated with $\mathrm{GA}_{3}(28.89 \mu \mathrm{M})$ that developed into callus and the regeneration of a new plant. d-e Seeds with no $\mathrm{GA}_{3}$ pretreatment with direct organogenesis. Barr: $3 \mathrm{~cm}$ 
silica semi polar capillary column (DB-5MS; 5\% phenyl $95 \%$ methylpolysiloxanes; $10 \mathrm{~m}$ length $\times 0.18 \mathrm{~mm}$ internal diameter $\times 0.18 \mu \mathrm{m}$ film thickness) was used with $\mathrm{He}$ as carrier gas with a constant flux of $1 \mathrm{~mL} / \mathrm{min}$. The injector temperature was $300^{\circ} \mathrm{C}$. The transference line temperature was $250^{\circ} \mathrm{C}$ and the source of ionization was $200^{\circ} \mathrm{C}$. The mass spectra were deconvoluted by AMDIS ${ }^{\circledR}$ (NIST, Gaithersburg, MD, USA) software and the compounds identified by comparing their mass spectral fragmentation and retention time with those of reference compounds spectra from NIST 05 database [NIST Mass Spectral Database, PCVersion 5.0 (2005) National Institute of Standardization and
Technology, Gaithersburg, MD, USA], standard references compounds and literature.

\section{Results and discussion}

Seed viability test

TTZ seed viability test indicated that only $50 \%$ of seeds of L. porteri maintained at $10^{\circ} \mathrm{C}$ and $-10^{\circ} \mathrm{C}$ for 45 days were viable. Seed viability results increased to $100 \%$ when seeds were stored at $1{ }^{\circ} \mathrm{C}$ for $45-90$ days.
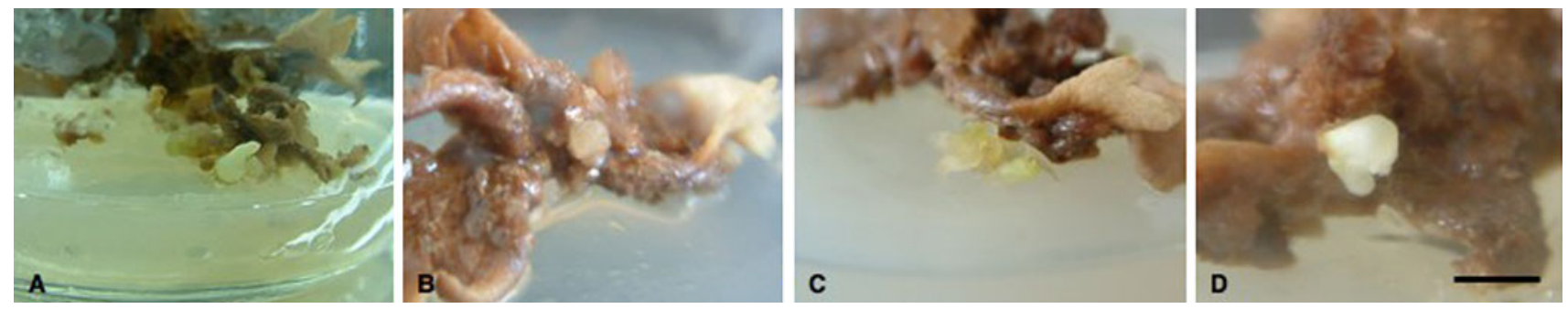

Fig. 2 Morphogenetic leaf of $L$. porteri cultured with 2,4-D $(9.05 \mu \mathrm{M})$ and BA $(4.44 \mu \mathrm{M})$. a Somatic embryo. b Cotyledonary-like stage embryo. c Nodular structures. d Pear-like structure embryo with a suspensor. Barr: $2 \mathrm{~cm}$
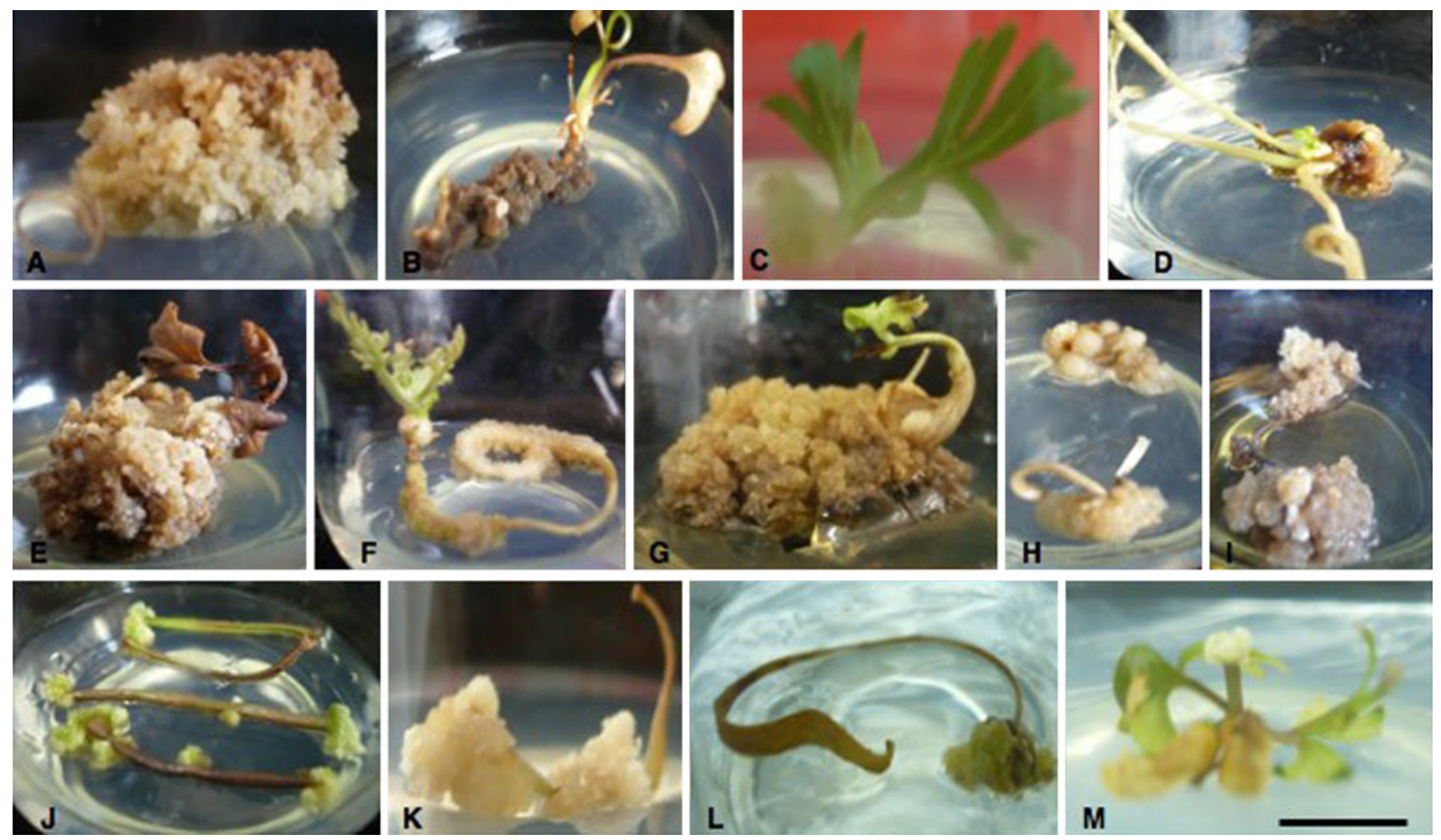

Fig. 3 Morphogenic responses of all explants of $L$. porteri. a Cotyledon NAA $(16.11 \mu \mathrm{M}) / \mathrm{BA}(4.44 \mu \mathrm{M})$, b root and stem NAA $(16.11 \mu \mathrm{M}) / \mathrm{BA}(4.44 \mu \mathrm{M})$, c leaf NAA $(16.11 \mu \mathrm{M}) / \mathrm{BA}(4.44 \mu \mathrm{M})$, d stem 2 ,4-D $(0.45 \mu \mathrm{M}) / \mathrm{BA}(4.44 \mu \mathrm{M})$, e leaf 2,4-D $(18.09 \mu \mathrm{M}) / \mathrm{BA}$ $(4.44 \mu \mathrm{M})$, f root and stem 2,4-D $(4.52 \mu \mathrm{M}) / \mathrm{BA}(4.44 \mu \mathrm{M})$, $\mathbf{g}$ stem

2,4-D $(18.09 \mu \mathrm{M}) / \mathrm{BA}(8.87 \mu \mathrm{M}), \mathbf{h}$ Cotyledon 2,4-D $(2.26 \mu \mathrm{M})$, i petiole NAA $(21.48 \mu \mathrm{M})$, j petioles $2,4-\mathrm{D}(0.45 \mu \mathrm{M}) / \mathrm{BA}(4.44 \mu \mathrm{M})$, $\mathbf{k}$ petiole 2,4-D $(13.57 \mu \mathrm{M}) / \mathrm{BA} \quad(4.44 \mu \mathrm{M}), \quad \mathrm{l}$ cotyledon $2,4-\mathrm{D}$ $(0.45 \mu \mathrm{M}) / \mathrm{BA}(2.22 \mu \mathrm{M})$, m leaf NAA $(0.54 \mu \mathrm{M}) / \mathrm{BA}(13.31 \mu \mathrm{M})$. Barr: $1.5 \mathrm{~cm}$ 

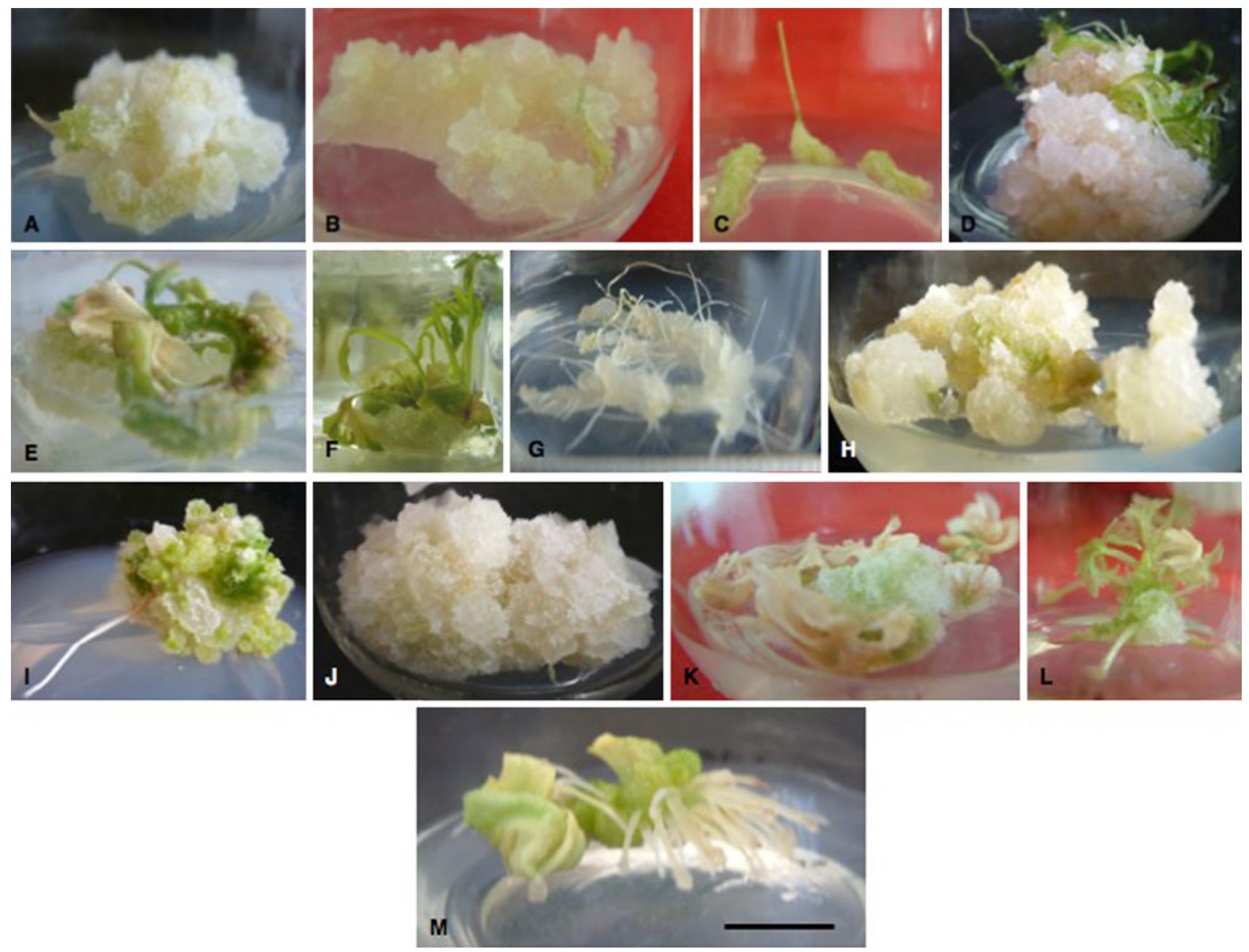

Fig. 4 Morphogenic responses of all explants of P. crispum. a. Leaf NAA $(21.48 \mu \mathrm{M}) / \mathrm{BA}(4.44 \mu \mathrm{M})$, b root $2,4-\mathrm{D} \quad(4.52 \mu \mathrm{M}) / \mathrm{BA}$ $(4.44 \mu \mathrm{M})$, c root and stem NAA $(21.48 \mu \mathrm{M})$, d petiole NAA $(16.11 \mu \mathrm{M}) / \mathrm{BA} \quad(2.22 \mu \mathrm{M})$, e cotyledon NAA $(21.48 \mu \mathrm{M}) / \mathrm{BA}$ $(2.22 \mu \mathrm{M})$, f leaf NAA $(0.54 \mu \mathrm{M}) / \mathrm{BA}(2.22 \mu \mathrm{M})$, g root NAA

Ex vitro germination

The three substrates [agrolite, Sphagnum and soil (1:1:1 v/ $\mathrm{v} / \mathrm{v})$; agrolite and soil $(1: 1 \mathrm{v} / \mathrm{v})$; and agrolite] did not influence germination of $L$. porteri seeds. In the case of seeds without cold pretreatment, the germination was low (5\%) and all the seedlings died after 12 weeks. Germination was higher (95\%) in the case of the seeds stored at $1{ }^{\circ} \mathrm{C}$ for 45 days and developed after 3-4 weeks regardless the substrate; the seedlings had a $100 \%$ survival rate. These plantlets had a healthy aspect, a fully expanded and green leaf and a long and thick root.

In vitro germination

Seeds of $L$. porteri pretreated with $28.89 \mu \mathrm{M}$ of gibberellic acid $\left(\mathrm{GA}_{3}\right)$ for $24 \mathrm{~h}$ did not germinate. Instead, $1.5 \%$ of
$(21.48 \mu \mathrm{M}) / \mathrm{BA}(4.44 \mu \mathrm{M}), \mathbf{h}$ petiole $2,4-\mathrm{D}(0.45 \mu \mathrm{M}) / \mathrm{BA}(4.44 \mu \mathrm{M})$, i cotyledon 2,4-D $(9.05 \mu \mathrm{M})$, j leaf BA $(4.44 \mu \mathrm{M})$, k leaf 2,4-D $(9.05 \mu \mathrm{M}) / \mathrm{BA}(4.44 \mu \mathrm{M})$, l stem NAA $(10.74 \mu \mathrm{M}) / \mathrm{BA}(4.44 \mu \mathrm{M})$, m leaf NAA $(21.48 \mu \mathrm{M})$. Barr: $1.5 \mathrm{~cm}$

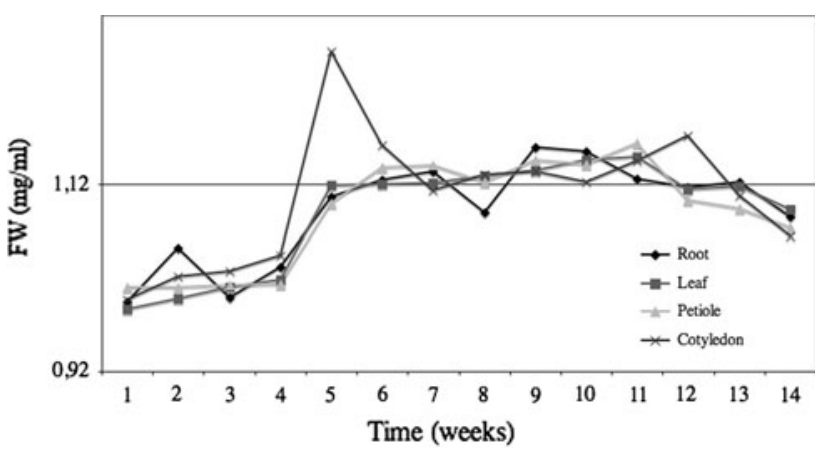

Fig. 5 Growth kinetics of all calli of $L$. porteri

embryos developed into callus and structures that resembled products of embryogenesis. They produced multiple petioles, axillary buds, curved adventitious-like buds, 

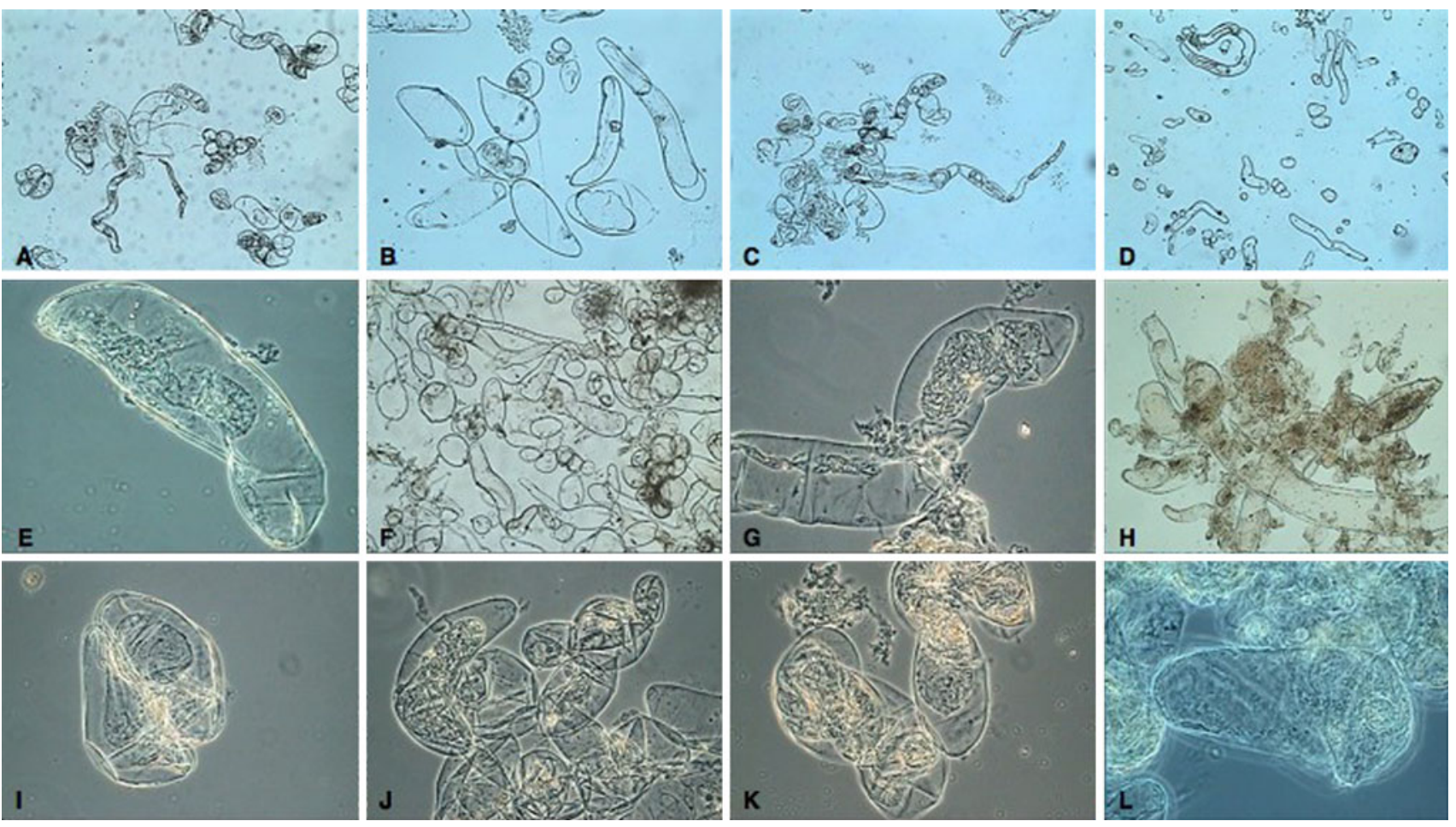

Fig. 6 Photomicrography of cell suspension cultures of $L$. porteri. a Cotyledon $\times 1,000 \mathrm{cp}$, b leaf $\times 2,000 \mathrm{cp}$, c petiole $\times 100 \mathrm{cp}$, $\mathbf{d}$ root $\times 100 \mathrm{cp}$, e cotyledon $\times 100 \mathrm{cp}$, f leaf $\times 200 \mathrm{cp}, \mathbf{g}$ petiole $\times 400 \mathrm{cp}$,

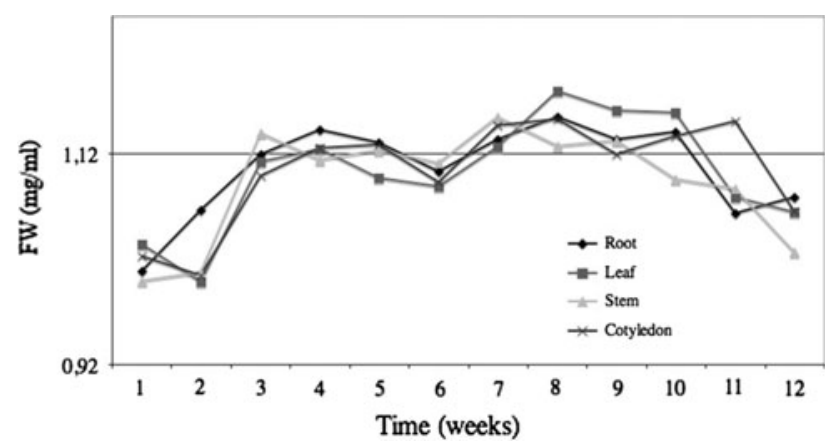

$\mathbf{h}$ root $\times 200 \mathrm{cp}, \mathbf{i}$ cotyledon $\times 400 \mathrm{cp}, \mathbf{j}$ leaf $\times 400 \mathrm{cp}, \mathbf{k}$ petiole $\times 400$ $\mathrm{cp}, \mathbf{l}$ root $\times 1,000$ cp. $n$ nucleus, $c c$ contracted cytoplasm

2 weeks, $P$. crispum germinated synchronously and all the seedlings survived.

Seeds of $L$. porteri cultured in a free of growth regulators MS medium showed a direct morphogenesis with organogenesis producing foliar, adventive and axillary buds. Plantlets had fully expanded leaves, stems, roots and sometimes cotyledon-like structures (Fig. 1d, e). These structures have a regenerative potential regardless of growth regulators in the medium. These results also revealed the high polymorphism of seeds as a result of a genetic recombination or the reaction to the in vitro conditions of a wild species.

a robust root, enlarged, concave and thick cotyledons and a large biomass in a free of growth regulators MS medium (Fig. 1a-c). This demonstrates that $\mathrm{GA}_{3}$ did not substitute cold treatment as reported for other species in the same family such as Chaerophyllum temulum (Vandelook et al. 2007) and Ferula gummosa (Nadjafi et al. 2006). The seeds of $L$. porteri with cold pretreatment germinated after five weeks of incubation in half strength MS media while those of $P$. crispum germinated in 2 weeks. The seeds of L. porteri germinated asynchronously (ca. $2 \% /$ week) after 5 weeks of incubation and the seedlings presented low survival $(50 \%)$ after 6 weeks. In contrast at the end of

\section{Plantlet decontamination}

Explants from plantlets of $L$. porteri grown ex vitro were difficult to establish aseptically in vitro. Thirteen combinations including PPM, amoxicillin, gentamicin (Salehi and Khosh-Khui 1997), terramycin, benomyl (Hauptmann et al. 1985) cuprimicin and thiabendazole (Tecto 60) were added to the media. Even though the combinations of fungicides and a mixture of all reagents were able to control the fungal contamination, all the explants died after 3 weeks. Consequently, plantlets derived from ex vitro germination were discarded. 

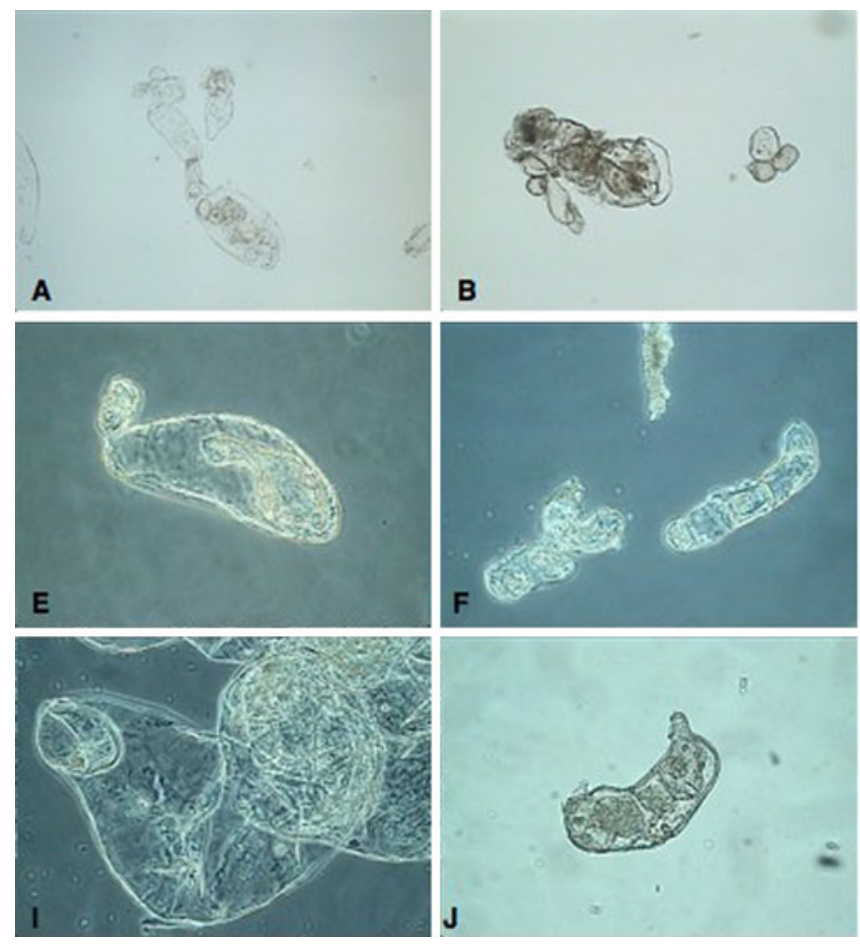

Fig. 8 Photomicrography of cell suspension cultures of $P$. crispum. a cotyledon $\times 100 \mathrm{cp}$, b leaf $\times 200 \mathrm{cp}, \mathbf{c}$ root $\times 200 \mathrm{cp}, \mathbf{d}$ stem $\times 200$ $\mathrm{cp}$, e cotyledon $\times 400 \mathrm{cp}, \mathbf{f}$ leaf $\times 400 \mathrm{cp}, \mathbf{g}$ root $\times 200 \mathrm{cp}, \mathbf{h}$ stem

\section{Morphogenetic cultures}

Only $2 \%$ of explants derived from leaf, root and stems of L. porteri, after induction to callus, resulted in the regeneration of a complete plantlet. Leaf explants cultured in a half strength MS medium supplemented with 2,4-D $(9.05 \mu \mathrm{M})$ and BA $(4.44 \mu \mathrm{M})$ developed into a white somatic embryolike organized structures. They resembled an embryo in the starch storage stage and developed hyaline nodules, roots, with a pear-like morphology and a short suspensor (Fig. 2a-d). They all developed from callus, resulting from an indirect morphogenesis.

\section{Callus induction}

Due to the low survival of $L$. porteri plantlets germinated in vitro, it was difficult to explore their response to different combinations of plant growth regulators. More than $80 \%$ of explants cultured in a half strength MS medium supplemented with 2,4-D $(9.05$ and $13.57 \mu \mathrm{M})$ and BA $(4.44 \mu \mathrm{M})$ developed into a yellowish, compact and non-friable callus in a period of 2-3 months (Fig. 1k). Limited growth was due to basal oxidization that progressed into the rest of the tissue. This oxidization was not lethal because the callus continued to grow slowly. After 30-40 days of induction, $90 \%$ of these explants became necrotic and died. About $20 \%$ of explants developed into
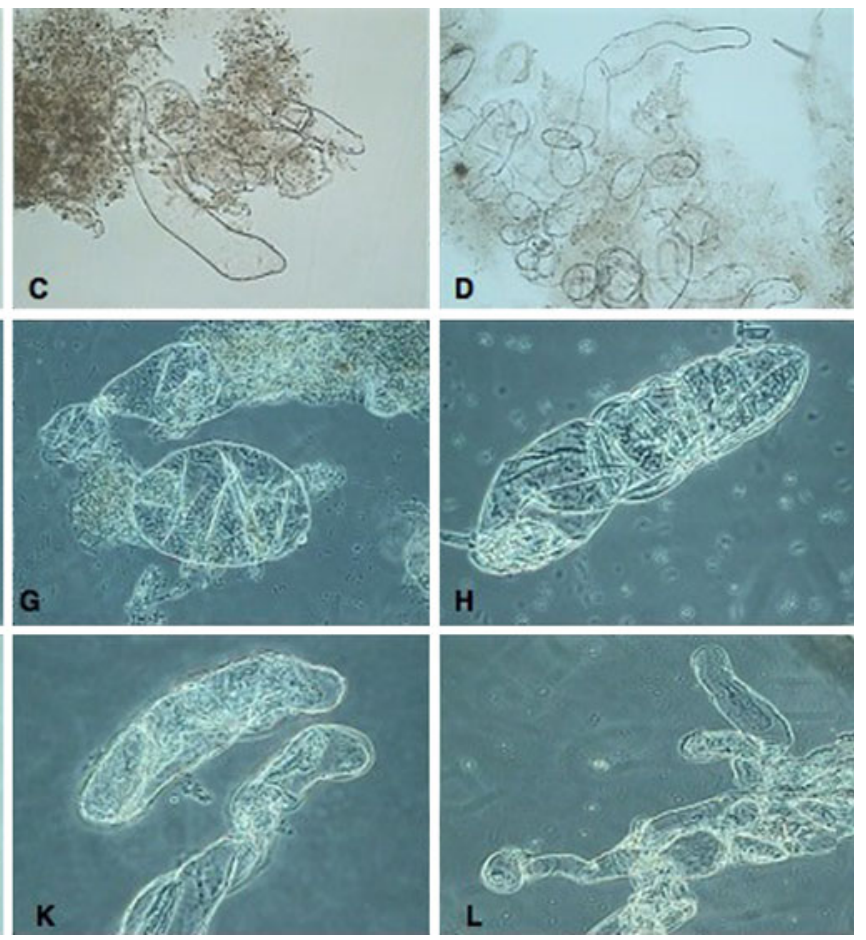

$\times 400 \mathrm{cp}, \mathbf{i}$ cotyledon $\times 400 \mathrm{cp}, \mathbf{j}$ leaf $\times 400 \mathrm{cp}, \mathbf{k}$ root $\times 400 \mathrm{cp}, \mathbf{l}$ stem $\times 200 \mathrm{cp}$. cn cellular content, $c c$ contracted cytoplasm

callus. Concentrations of NAA $(16.11 \mu \mathrm{M})$ and BA $(4.44 \mu \mathrm{M})$ resulted in a faster morphogenetic response. However, 90\% of explants died and a lower quantity of callus were obtained compared to that of 2,4-D $(4.52-18.09 \mu \mathrm{M})$. Explant induction at concentrations of NAA $(21.48 \mu \mathrm{M})$ and BA $(4.44 \mu \mathrm{M})$ occurred after 1 month of culture but $95 \%$ explants died. This callus developed secondary roots and leaves with extended petioles regardless of the origin of the explant (Fig. 3b, d, f). In the case where the stem and root were intact in the explant, leaves developed from the stem portion. On the other hand, survival of $P$. crispum plantlets was $100 \%$ and all explants that were cultured with 2,4-D $(0-18.09 \mu \mathrm{M})$ or NAA $(0-21.48 \mu \mathrm{M})$ in combination with BA $(0-13.31 \mu \mathrm{M})$ developed into a green or hyaline, loose, wet and highly friable callus in less than 30 days (Fig. 4). The combination that gave rise to the highest number of callus was NAA $(21.48 \mu \mathrm{M}) / \mathrm{BA} \quad(4.44 \mu \mathrm{M})$ and $2,4-\mathrm{D} \quad(18.09 \mu \mathrm{M}) / \mathrm{BA}$ $(4.44 \mu \mathrm{M})$. Leaf and root explants cultured with high auxin concentrations developed secondary hyaline, thin roots (Fig. 4g, m). After this time, all callus from both species was cut into $2-3 \mathrm{~cm}^{3}$ pieces and transferred to $25 \mathrm{~mL}$ a half strength liquid MS media, under which they proliferated rapidly. Over $90 \%$ of the explants of the wild species became necrotic as auxin concentrations increased and the remainder developed into small to medium size, hard, yellowish callus; in contrast all the explants of the 
cultivated species produced a lot of friable, green-transparent callus regardless of the concentration of plant growth regulators.

\section{Growth kinetics}

The growth curves of $L$. porteri calli illustrate a typical sigmoid pattern (Fig. 5). Lag phase had no cell division signal (Fig. 4a-d), cellular morphology was elongated primarily and 1-2 $\mathrm{mm}$ aggregates and isolated cells were observed. Some cells presented an expanded (Fig. 6b, c) or contracted (Fig. 6i) cytoplasm. Cellular contents (Fig. 6e-h) and nuclei (Fig. 6k) were visible in the later phases.

In the case of P. crispum (Fig. 7), all explants, except the root culture, exhibited a similar behavior. In the sixth week the culture conditions may not have been appropriate or the factors became limiting because all explants decreased notably in biomass $\left(0.8 \mathrm{mg} \mathrm{mL}^{-1} \mathrm{FW}\right.$ After the seventh week all explants increased their biomass (1.4 $\mathrm{mg} \mathrm{mL}^{-1} \mathrm{FW}$ but declined after that. The cells enlarge in size as well as their vacuole (Fig. 8a-c). Clustered (Fig. 8E) or solitary (Fig. 8d) cells as well as cellular content were visible (Fig. 8h, j).

\section{Extract analysis}

Eight-month-old roots of $L$. porteri and $P$. crispum (Table 2) cultivated in greenhouse were analyzed by GC-MS. Analyses revealed the presence of 3-butylidenephthalide $(20.85 \%)$ (3) in the former and 3- $n$-butylphthalide $(0.72 \%)(4)$ and 3,6,7-trimethoxy-isobenzofuran$13(\mathrm{H})$-one $(4.99 \%)(5)$ in the latter. Other metabolites like ferulic acid (1.67\%) (6), 5,7,8-trimethyldihydrocoumarin (6.73\%) (7), psoralen (2.62\%) (8), apiol (23.51\%) (9), 2-methoxy-4-vinylphenol (1.16\%) (10) and falcarinol $(17.56 \%)(11)$, naturally occurring to the Apiaceae, were also found to be present (Fig. 9).

$\beta$-Caryophyllene $(34.7 \%)$ and germacrene $\mathrm{D}(65.4 \%)$ were the only components in the seeds $(9.81 \mathrm{~g})$ of L. porter. E-butylidenephthalide (6.3\%) (2) was the only phthalide identified in the extract (fraction III-B) from the aerial parts of L. porter. Carvacrol, germacrene D, $\beta$-bisabolene $(33.80 \%)$, apiol elemicin, $\alpha$-spathulenol, oplopanone and scoparone were other common compounds detected in the remaining fractions of this extract (Table 3). It should be noted that this is the first report of the presence of a phthalide in the aerial parts of $L$. porteri.

Previous investigations revealed that the variation in contents of the essential oils between a wild and a cultivated species belonging to the same family is very high, even in the same species, these differences become visible. Staniszewska et al. (2005) found in Daucus carota ssp. carota and D. carota ssp. sativus a variation in monoterpenoids and sesquiterpenoids content; in the wild subspecies the monoterpenoids were in high concentrations but carotol, daucol and daucene were not detected. On the other hand, the cultivated subspecies contained a high concentration of carotol and low concentrations of monoterpenoids.

L. porteri and $P$. crispum share some characteristic components such as phthalides and phenylpropanoids. Both species accumulate a wide array of metabolites that play a defense role against several microorganisms and herbivores, which surround its environment. It is possible that the chemical composition of the root of $L$. porteri could change if it is domesticated, although the presence of phthalides is a character that has not been altered over the course of domestication.

Calli analysis. GC-MS analysis of the calli of $L$. porteri revealed that $Z$-ligustilide was not present. Nevertheless, 2-methoxy-4-vinylphenol (0.17-46.92\%), thymol (0.06\%), apiol (0.53-21.05\%), falcarinol (3.01-12.91\%), acetovanillone (2.65-3.17\%), 4-methoxtcinnamate (7.69-100\%)

Table 2 Components in the root extracts of $L$. porteri and P. crispum (relative abundance, \%)

\begin{tabular}{|c|c|c|c|}
\hline Component & $\begin{array}{l}\text { R.T. } \\
(\min )\end{array}$ & $\begin{array}{l}\text { L.p. } \\
\%\end{array}$ & $\begin{array}{l}\text { P.c. } \\
\%\end{array}$ \\
\hline$p$-Cimene & 1.87 & 0.32 & - \\
\hline Sabinene & 1.91 & 0.12 & - \\
\hline E-2-Nonenal & 2.56 & 1.47 & 1.16 \\
\hline 2-Methoxy-4-vinylphenol & 3.32 & 0.43 & - \\
\hline 4,7-Dihydroisobenzofuran-1,3-dione & 3.52 & 22.02 & - \\
\hline 3-Hydroxy-4-methoxymandelic acid & 3.73 & 0.16 & - \\
\hline Apiol & 4.65 & 0.41 & 13.37 \\
\hline 3-Butylidenephthalide & 4.89 & 20.85 & - \\
\hline $5,7,8$-Trimethyldihydrocoumarin & 5.16 & 6.73 & - \\
\hline Vanillin & 5.47 & - & 0.002 \\
\hline Ferulic acid & 5.68 & 1.67 & - \\
\hline$n$-Hexadecanoic acid & 5.91 & 8.10 & 0.77 \\
\hline$\beta$-Sesquiphellandrene & 6.31 & - & 9.38 \\
\hline Elemicin & 6.46 & - & 1.78 \\
\hline $1, E-11, Z$-13-Octadecatriene & 6.47 & - & 3.69 \\
\hline 3-n-Butylphthalide & 7.06 & - & 0.72 \\
\hline Coniferol & 7.53 & - & 0.99 \\
\hline Psoralen & 7.98 & - & 2.62 \\
\hline Falcarinol & 9.09 & - & 17.56 \\
\hline $\begin{array}{l}\text { 3,6,7-Trimethoxy-isobenzofuran-13(H)- } \\
\text { one }\end{array}$ & 9.23 & - & 4.99 \\
\hline Octadecanoic acid & 9.69 & - & 0.42 \\
\hline $\begin{array}{l}\text { Hexadecanoic acid, 2-hydroxy-1- } \\
\text { (hydroxymethyl)ethyl ester }\end{array}$ & 11.12 & - & 1.79 \\
\hline Tetracosanoic acid & 12.12 & - & 2.74 \\
\hline Stigmasterol & 13.64 & - & 11.65 \\
\hline$\beta$-Sitosterol & 13.83 & - & 7.78 \\
\hline
\end{tabular}


Fig. 9 Chemical structures of $Z$-Ligustilide (1), E-

Butylidenephthalide (2),

3-Butylidenephthalide (3),

3- $n$-Butylphthalide (4),

3,6,7-Trimethoxy-

isobenzofuran-13(H)-one (5),

Ferulic acid (6),

5,7,8-Trimethyldihydro-

coumarin (7), Psoralen (8),

Apiol (9), 2-Methoxy-4-

vinylphenol (10)

and Falcarinol (11)
(1)<smiles>CCC/C=C1\OC(=O)C2=C1CCC=C2</smiles>

Z.L.logustilide

(4)<smiles>CCC/C=C1\OC(=O)c2ccccc21</smiles>

(2)<smiles>CCCCC1OC(=O)C2CCCCC12</smiles>

(3)

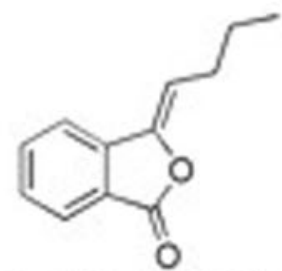

-Butylidenephralide 3-Butylidenephthatide<smiles>[131IH]</smiles><smiles>COc1ccc2c(c1OC)C(=O)OC2OC</smiles>

3-n-Butylphthalide 3,6,7-trimethoxy-isobenxofuram-13(II)-one

(6)<smiles>COc1cc(/C=C/C(=O)O)ccc1O</smiles>

Feralic acid

(7)<smiles>Cc1cc(C)c2c(c1C)OC(=O)CC2</smiles>

8,7,8-trime thyldihydrocoumarin

(9)<smiles>C=CCc1cc(OCCO)c2c(c1OC)OCO2</smiles>

(8)<smiles>O=c1ccc2cc3ccoc3cc2o1</smiles>

(10)<smiles>C#Cc1ccc(O)c(OC)c1</smiles>

2-Methoxy-4-vinylphenol

(11)

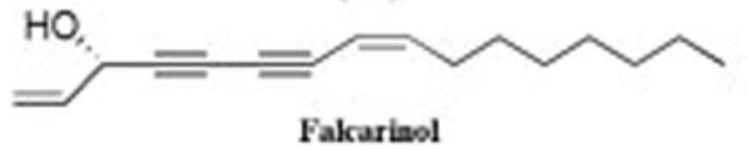


Table 3 Components in the aerial parts of $L$. porteri (relative abundance, \%)

\begin{tabular}{|c|c|c|c|}
\hline Fraction & Component & R.T. (min) & $\%$ \\
\hline \multirow[t]{8}{*}{ I } & Carvacrol & 3.68 & 13.79 \\
\hline & $\alpha$-Copaene & 4.24 & 0.93 \\
\hline & $\alpha$-Bourbonene & 4.27 & 0.96 \\
\hline & Germacrene D & 4.51 & 19.94 \\
\hline & $\beta$-Bisabolene & 4.58 & 33.80 \\
\hline & $\alpha$-Calacorene & 4.70 & 5.94 \\
\hline & Cadala-1(10),3,8-triene & 5.01 & 2.04 \\
\hline & 3-(4,8,12-Trimethyltridecyl) furan & 5.58 & 22.56 \\
\hline \multirow[t]{2}{*}{ II } & Myristicin & 7.67 & 12.76 \\
\hline & Apiol & 8.27 & 87.23 \\
\hline \multirow[t]{4}{*}{ III-A } & Elemicin & 4.71 & 32.16 \\
\hline & $\alpha$-Spathulenol & 4.80 & 48.88 \\
\hline & $\alpha$-Cadinol & 4.97 & 7.67 \\
\hline & $\begin{array}{l}\text { 6-Isopropenil-4,8a-dimethyl-1,2,3,5,6, } \\
\text { 7,8,8a-octahydro-naphthalen-2-ol }\end{array}$ & 5.06 & 1.83 \\
\hline \multirow[t]{5}{*}{ III-B } & Elemicin & 4.69 & 1.42 \\
\hline & $\alpha$-Spathulenol & 4.82 & 7.73 \\
\hline & Apiol & 4.89 & 57.23 \\
\hline & $E$-Butylidenephthalide & 5.03 & 6.35 \\
\hline & $\begin{array}{l}\text { (7R,8R)-bicyclo(5,3,1)undec-1-ene-8-ol, } \\
\text { 7-methyl-4-(1-methyletilidene) }\end{array}$ & 5.06 & 22.46 \\
\hline \multirow[t]{4}{*}{ IV } & Carvacrol & 2.40 & 53.48 \\
\hline & Dihydroactinidiolide & 4.11 & 2.38 \\
\hline & 2,5-Octadecadiynoic acid, methyl ester & 4.33 & 31.99 \\
\hline & Phytone & 4.94 & 12.13 \\
\hline V & Oplopanone & 8.97 & 1.02 \\
\hline VI & Scoparone & 5.43 & 100 \\
\hline VII & Phytol & 5.03 & 39.97 \\
\hline
\end{tabular}

and $\beta$-hydroxypropiovanillone $(2.12 \%)$ were some of the most abundant components in the analyzed samples (Table 4). Stahl-Biskup and Wichtmann (1991) mentioned that the absence of phthalides in the callus extracts of Levisticum officinale was due to the lack of resiniferous ducts that are necessary for their biosynthesis and a minimum degree of differentiation was necessary for this biosynthesis.

3-Butylidenephthalide was the only phthalide detected in one stem $(0.82 \%)$ and two petiole callus extracts $(0.99$ and $0.26 \%$ ). Although the calli had no physiological or structural differentiation, the phthalides biosynthesis was expressed. The results of Smitt et al. (1996) with callus, suspension cultures, elicitation of cotyledons and roots as well as genetically transformed cultures of Thapsia garganica revealed that no thapsigargins were present, suggesting that a cellular differentiation was needed for their biosynthesis.

3-Butylidenephthalide has acaricidal activity against larvae of Dermatophagoides farinae $\left(6.77 \mu \mathrm{g} \mathrm{cm}^{2}-1\right)$ and adults of D. pteronyssinus $\left(6.46 \mu \mathrm{g} \mathrm{cm}^{2}-1\right)$ (Kwon and Ahn 2002). It also has insecticidal activity against larvae of Drosophila melanogaster $\left(0.94 \mu \mathrm{mol} \mathrm{mL}{ }^{-1}\right)$ and is the most active compound compared to Z-ligustilide and two furanocoumarins (xanthotoxin and isompimpinellin) (Miyazawa et al. 2004). These biological activities suggest the potential of 3-butylidenephthalide as a non-toxic and biodegradable natural pesticide, at a low concentration.

Al-Abta et al. (1979) obtained 3-isobutylidene-3a,4,5, 6-tetrahydrophthalide and 3-isobutylidene-3a,4-dihydrophthalide from differentiated callus with embryonary structures in the globular and hearth-shaped stages and from intact plants of Apium graveolens "Lathom Blanching". These cultures were grown in MS medium supplemented with 2,4D $(22.62 \mu \mathrm{M})$, further transferred to liquid MS medium without growth regulators, where they obtained similar quantities of these phthalides to that of the intact plant from cultures in the torpedo embryonic stage. Authors concluded that at this stage and more advanced ones, the tissues may have higher capability to accumulate or increase their 
Table 4 Chemical composition in the calli extracts of $L$. porteri (relative abundance, $\%$ )

\begin{tabular}{|c|c|c|c|}
\hline Explant & Component & R.T. (min) & $\%$ \\
\hline \multirow[t]{5}{*}{ Root I } & Z-2-Heptenal & 3.29 & 16.08 \\
\hline & 2-Methoxy-4-vinylphenol & 6.50 & 3.90 \\
\hline & $n$-Hexadecanoic acid & 10.24 & 55.87 \\
\hline & Octadecanoic acid, methyl ester & 10.88 & 0.82 \\
\hline & Hexadecanoic acid, 2,3-dihydroxypropyl ester & 12.55 & 13.91 \\
\hline \multirow[t]{6}{*}{ Seeds } & Benzothiazole & 5.95 & 0.74 \\
\hline & Propanoic acid, 2-methyl-, 3-hydroxy-2,4,4-trimethylpentyl ester & 6.84 & 8.52 \\
\hline & 1-Hexadecanol & 9.72 & 8.00 \\
\hline & $n$-Hexadecanoic acid & 10.21 & 45.88 \\
\hline & Octadecanoic acid, methyl ester & 10.88 & 2.64 \\
\hline & 9-Hexadecanoic acid & 11.02 & 34.19 \\
\hline Cotyledon & 4-Metoxyicinnamate & 11.80 & 100 \\
\hline Leaf & Acetovanillone & 5.40 & 2.65 \\
\hline \multirow[t]{3}{*}{ Root II } & 5-Methyl-2-furancarboxaldehyde & 1.78 & 8.57 \\
\hline & 5-Hydroxymethyl-2-furancarboxaldehyde & 3.78 & 85.04 \\
\hline & $n$-Hexadecanoic acid & 8.06 & 2.10 \\
\hline \multirow[t]{2}{*}{ Petiole I } & 2-Methoxy-4-vinylphenol & 4.87 & 46.92 \\
\hline & $n$-Hexadecanoic acid & 8.73 & 45.38 \\
\hline \multirow[t]{11}{*}{ Stem } & Carvacrol & 3.21 & 0.06 \\
\hline & $(E, E)$-2,4-Decadienal & 3.22 & 3.65 \\
\hline & 2-Methoxy-4-vinylphenol & 3.31 & 1.90 \\
\hline & Apiol & 4.65 & 0.53 \\
\hline & 3-Butylidenephthalide & 4.87 & 0.82 \\
\hline & $n$-Hexadecanoic acid & 5.88 & 10.65 \\
\hline & Falcarinol & 6.15 & 11.56 \\
\hline & $(11 E, 13 Z)$-Octadeca-1,11,13-triene & 6.45 & 9.25 \\
\hline & 1,2-Benzenedicarboxylic acid, mono(2-ethylhexyl) ester & 7.60 & 39.39 \\
\hline & Stigmasterol & 9.70 & 0.39 \\
\hline & 22,23-Dihydro-stigmasterol & 9.96 & 1.21 \\
\hline \multirow[t]{20}{*}{ Petiole II } & $(E, E)$-2,4-Heptadienal & 1.72 & 0.41 \\
\hline & 2-Methoxy-4-vinylphenol & 3.31 & 0.17 \\
\hline & $(E, E)-2,4-$ Decadienal & 3.34 & 4.82 \\
\hline & Apiol & 4.65 & 21.05 \\
\hline & 3-Butylidenephthalide & 4.87 & 0.99 \\
\hline & Hexadecanal & 5.00 & 0.29 \\
\hline & Eicosane & 5.30 & 0.43 \\
\hline & trans-Phytol & 5.44 & 3.50 \\
\hline & Tridecanoic acid, methyl ester & 5.75 & 0.95 \\
\hline & $n$-Hexadecanoic acid & 5.92 & 5.35 \\
\hline & Isopropyl palmitate & 6.08 & 1.98 \\
\hline & Falcarinol & 6.15 & 3.01 \\
\hline & trans-9-Hexadecen-1-ol & 6.29 & 2.14 \\
\hline & Phytol & 6.36 & 0.08 \\
\hline & 9-Octadecynoic acid & 6.48 & 11.43 \\
\hline & $9,12,15$-Octadecatrienal & 6.50 & 1.17 \\
\hline & Octadecanoic acid & 6.55 & 3.47 \\
\hline & Hexadecanoic acid, 2-hydroxy-1-(hydroxymethyl)ethyl ester & 7.56 & 6.44 \\
\hline & Stigmasterol & 9.71 & 10.64 \\
\hline & 22,23-Dihydro-stigmasterol & 10.01 & 3.06 \\
\hline
\end{tabular}


Table 4 continued

\begin{tabular}{llrr}
\hline Explant & Component & R.T. $(\mathrm{min})$ & \multicolumn{1}{c}{$\%$} \\
\hline Root III & (E,E)-2,4-Decadienal & 3.34 & 5.40 \\
& 1,2-Benzenedicarboxylic acid, dihexyl ester & 5.87 & 13.45 \\
& 1,E-11,Z-13-Octadecatriene & 6.44 & 20.60 \\
& 1,2-Benzenedicarboxylic acid, mono(2-ethylhexyl) ester & 7.60 & 3.88 \\
& $\beta$-Sitosterol & 9.96 & 8.41 \\
Petiole III & (E, E)-2,4-Decadienal & 3.34 & 0.88 \\
& Apiol & 4.65 & 5.60 \\
& 3-Butylidenephthalide & 4.87 & 0.26 \\
& trans-9-Hexadecen-1-ol & 5.61 & 0.03 \\
& Tridecanoic acid, methyl ester & 5.75 & 0.27 \\
& $n$-Hexadecanoic acid & 5.89 & 11.65 \\
& 9-endo-Hydroxy-9-exo-vinylbicyclo(4,2,1)-nona-2,4-diene & 5.97 & 0.61 \\
& Falcarinol & 6.15 & 12.91 \\
& 9,12-Octadecadienoic acid, methyl ester & 6.31 & 0.24 \\
& 9,12-Octadecadienal & 6.46 & 13.60 \\
Octadecanoic acid & 6.54 & 0.41 \\
& Hexadecanoic acid, 2-hydroxy-1-(hydroxymethyl)ethyl ester & 7.56 & 1.25 \\
Stigmasterol & 9.70 & 4.57 \\
22,23-Dihydro-stigmasterol & 9.98 & 9.33 \\
\hline
\end{tabular}

biochemical ability to synthesize phthalides regarding the differentiation of specific cellular types.

Watts et al. (1984) obtained 3-n-butylphthalide and sedanolide in vitro from suspension cultures of $A$. graveolens in liquid MS medium supplemented with 2,4-D (2.26 $\mu \mathrm{M})$ and Kinetin $(2.79 \mu \mathrm{M})$. They observed that the substitution of 2,4-D for 3,5-dichlorophenoxyacetic acid in illuminated and aggregated cultures, the phthalides biosynthesis increased along with the terpenoid limonene.

One of the hypotheses is that the secondary metabolite biosynthesis in non-differentiated cellular cultures can be achieved with the modification of the growth pattern. Watts et al. (1985) compared the relationship among the cellular differentiation, the secondary metabolite biosynthesis and the greening of the suspension cultures of A. graveolens. They concluded that phthalides and limonoid biosynthesis decreased when the cellular aggregation increased and with greening.

\section{Conclusions}

Because $L$. porteri is a vulnerable plant in its natural environment and there is a huge market for its roots, the present study is very important, as it demonstrates an efficient and simple protocol that enables the potential use of its organs as an alternative source of phthalides, which will contribute to its conservation.

Acknowledgments We acknowledge financial support from Secretaría de Educación Pública (SEP) and Consejo Nacional de Ciencia y Tecnología (CONACYT), Programa de Apoyo a Proyectos de Investigación e Innovación Tecnológica (PAPIIT), Dirección General de Asuntos del Personal Académico (DGAPA) and Universidad Nacional Autónoma de México (UNAM). We also thank CONACYT for the scholarship (to DG) given through the postgraduate program of Biological Sciences-UNAM and the technical assistance of Laura Acevedo (Faculty of Chemistry, UNAM), Isabel Rivero (Faculty of Chemistry, UNAM), Georgina Duarte (Faculty of Chemistry, UNAM), Estela Sandoval (Botanical Garden, UNAM), Concepción Guzmán (Botanical Garden, UNAM) and Bárbara Estrada (Botanical Garden, UNAM)

Open Access This article is distributed under the terms of the Creative Commons Attribution License which permits any use, distribution, and reproduction in any medium, provided the original author(s) and the source are credited.

\section{References}

Al-Abta S, Galpin IJ, Collin HA (1979) Flavour compounds in tissue cultures of celery. Plant Sci Lett 16:129-134

Appelt GD (1985) Pharmacological aspects of selected herbs employed in Hispanic folk medicine in the San Luis Valley of Colorado, USA: I. Ligusticum porteri (osha) and Matricaria chamomilla (manzanilla). J Ethnopharmacol 13:51-55

Bairamian S, Beauchamp PS, Descalzo JT, Dev BC, Dev V, Frost SC, Nguyen CV (2004) California Lomatiums Part III. Composition of the hydrodistilled oils from two varieties of Lomatium dissectum. Isolation of a new hydrocarbon. J Essent Oil Res 16:461-468

Brindis F, Rodríguez R, Bye R, González-Andrade M, Mata R (2011) (Z)-3-Butylidenephthalide from Ligusticum porteri, an $\alpha$-glucosidase inhibitor. J Nat Prod 74:314-320

Bye RA (1985) Medicinal plants of the Tarahumara Indians of Chihuahua, Mexico. In: Tyson RA, Elerick DV (eds) Two 
mummies from Chihuahua, Mexico. A multidisciplinary study. San Diego Museum Papers no 19. San Diego Museum of Man, pp 77-103

Camazine S, Bye RA (1980) A study of the medicinal ethnobotany of the Zuni Indians of New Mexico. J Ethnopharmacol 2:365-388

Chan SS, On-Ki A, Jones RL, Lin G (2006) Mechanisms underlying the vasorelaxing effects of butylidenephthalide, an active constituent of Ligusticum chuanxiong, in rat isolated aorta. Eur J Pharmacol 537:111-117

Cronquist A (1997) Apiaceae. In: Cronquist A, Holmgren NH, Holmgren PK (eds) Intermountain flora. Vascular plants of the intermountain West, USA, vol 3 part A. Subclass Rosidae (except Fabales). The New York Botanical Garden Bronx, New York, pp 340-341, 365-367

Delgado G, Reza-Garduño RG, Toscano RA, Bye RA, Linares E (1988) Secondary metabolites from the roots of Ligusticum porteri (Umbelliferae). X-Ray structure of $Z-6.6^{\prime}, 7.3^{\mathrm{a}}$ '-diligustilide. Heterocycles 27:1305-1312

Deng S, Chen SN, Lu J, Wang ZJ, Nikolic D, van Breemen RB, Santarsiero BD, Mesecar A, Fong HH, Farnsworth NR, Pauli GF (2006a) GABAergic phthalide dimers from Angelica sinensis (Oliv.) Diels. Phytochem Anal 17:398-405

Deng S, Chen SN, Yao P, Nikolic D, van Breemen RB, Bolton JL, Fong HH, Farnsworth NR, Pauli GF (2006b) Serotonergic activity-guided phytochemical investigation of the roots of Angelica sinensis. J Nat Prod 69:536-541

Du J, Bai B, Kuang X, Yu Y, Wang C, Ke Y, Xu Y, Tzang A, Qian ZM (2006) Ligustilide inhibits spontaneous and agonists- or $\mathrm{K}^{+}$ depolarization-induced contraction of rat uterus. J Ethnopharmacol 108:54-58

Fischer FC, Gijbels MJ (1987) cis- and trans-neocnidilide; ${ }^{1} \mathrm{H}-$ and ${ }^{13} \mathrm{C}-\mathrm{NMR}$ data of some phthalides. Planta Med 53:77-80

Gijbels MJ, Scheffer JJ, Svendsen AB (1979) Phthalides in Umbelliferae. Riv Ital EPPOS 51:335-341

Gijbels MJ, Scheffer JJ, Svendsen AB (1981) Analysis of phthalides from Umbelliferae by combined liquid-solid and gas-liquid chromatography. Chromatographia 14:452-454

Gijbels MJ, Bos R, Scheffer JJ, Svendsen AB (1983) Phthalides in roots of Opopanax chironium. Planta Med 47:3-6

Gijbels MJ, Fischer FC, Scheffer JJ, Svendsen AB (1984) Phthalides in roots of Capnophyllum peregrinum and Peucedanum ostruthium. Planta Med 50:110

Gijbels MJ, Fischer RC, Scheffer JJ, Svendsen AB (1985) Phthalides in roots of Apium graveolens, A. graveolens var. rapaceum, Bifora testiculata and Petroselinum crispum var. tuberosum. Fitoterapia 56:17-23

Hauptmann RM, Widholm JM, Paxton JD (1985) Benomyl: a broadspectrum fungicide for use in plant cell and protoplast culture. Plant Cell Rep 4:129-132

Kuang X, Yao Y, Du JR, Liu YX, Wang CY, Qian ZM (2006) Neuroprotective role of Z-ligustilide against forebrain ischemic injury in ICR mice. Brain Res 1102:145-153

Kwon JH, Ahn YJ (2002) Acaricidal activity of butylidenephthalide identified in Cnidium officinale rhizome against Dermatophagoides farinae and Dermatophagoides pteronyssinus (Acari: Pyroglyphidae). J Agric Food Chem 50:4479-4483

Lao SC, Li SP, Kan KW, Li P, Wan JB, Wang YT, Dong TT, Tsim KW (2004) Identification and quantification of 13 components in Angelica sinensis (Danggui) by gas chromatography-mass spectrometry coupled with pressurized liquid extraction. Anal Chim Acta 526:131-137

León A, Toscano RA, Tortoriello J, Delgado G (2011) Phthalides and other constituents from Ligusticum porteri; sedative and spasmolytic activities of some natural products and derivatives. Nat Prod Res 25:1234-1242

Liang MJ, He LC (2006) Inhibitory effects of ligustilide and butylidenephthalide on bFGF-stimulated proliferation of rat smooth muscle cells. Yao Xue Xue Bao 41:161-165

Linares E, Bye RA (1987) A study of four medicinal plant complexes of Mexico and adjacent United States. J Ethnopharmacol 19: 153-183

Lu Q, Qiu TQ, Yang H (2006) Ligustilide inhibits vascular smooth muscle cells proliferation. Eur J Pharmacol 542:136-140

MacLeod AJ, Macleod G, Subramanian G (1988) Volatile aroma constituents of celery. Phytochemistry 27:373-375

Miyazawa M, Tsukamoto T, Anzai J, Ishikawa Y (2004) Insecticidal effect of phthalides and furanocoumarins from Angelica acutiloba against Drosophila melanogaster. J Agric Food Chem 52:4401-4405

Murashige T, Skoog F (1962) A revised medium for rapid growth and bioassays with tobacco tissue cultures. Physiol Plant 15:473-497

Nadjafi F, Bannayan M, Tabrizi L, Rastgoo M (2006) Seed germination and dormancy breaking techniques for Ferula gummosa and Teucrium polium. J Arid Environ 64:542-547

Ortíz BI, Shields KM, Clauson KA, Clay PG (2007) Complementary and alternative medicine use among Hispanics in the United States. Ann Pharmacother 41:994-1004

Palá-Paúl J, García-Jiménez R, Pérez-Alonso MJ, Velasco-Negueruela A, Sanz J (2004) Essential oil of the leaves and stems of Meum athamanticum Jacq. from Spain. J Chromatogr A 1036: 245-257

Peng HY, Du JR, Zhang GY, Kuang X, Liu YX, Qian ZM, Wang CY (2007) Neuroprotective effect of $Z$-ligustilide against permanent focal ischemic damage in rats. Biol Pharm Bull 30:309-312

Salehi H, Khosh-Khui M (1997) A simple procedure for disinfection of "Baby Masquerade" miniature rose explants. Sci Hort 68:145-148

Santos PA, Figueiredo AC, Oliveira MM, Barroso JG, Pedro LG, Deans SG, Scheffer JJ (2005) Growth and essential oil composition of hairy root cultures of Levisticum officinale W.D.J. Koch (lovage). Plant Sci 168:1089-1096

Schmidt L (2000) Guide to handling of tropical and subtropical forest seed. Danida Forest Seed Centre, Hoersholm

Smitt UW, Jager AK, Nyman U (1996) Thapsia garganica L.: In vitro culture, somatic embryogenesis and the production of thapsigargins. In: Bajaj YPS (ed) Biotechnology in agriculture and forestry, vol 37. Springer, Berlin, pp 402-409

Stahl-Biskup E, Wichtmann EM (1991) Composition of the essential oils from roots of some Apiaceae in relation to the development of their oil duct systems. Flavour Fragr J 6:249-255

Staniszewska M, Kula J, Wieczorkiewicz M, Kusewicz D (2005) Essential oils of wild and cultivated carrots-the chemical composition and antimicrobial activity. J Essent Oil Res 17: $579-583$

Street HE (1977) Plant tissue and cell culture. Blackwell Scientific Publications, Oxford

Vandelook F, Bolle N, Assche JA (2007) Seed dormancy and germination of the European Chaerophyllum temulum (Apiaceae), a member of a trans-Atlantic genus. Ann Bot 100:233-239

Watts MJ, Galpin IJ, Collin HA (1984) The effect of growth regulators, light and temperature on flavour production in celery tissue cultures. New Phytol 98:583-591

Watts MJ, Galpin IJ, Collin HA (1985) The effect of greening on flavour production in celery tissue cultures. New Phytol 100:45-56 